\title{
Observații asupra limbii lui Petru Maior în Învățătură pentru ferirea și doftoria boalelor
}

\author{
Liliana Soare* \\ Facultatea de Litere, Universitatea din Pitești, Str. Gh. Doja 41, 110253 Pitești, România
}

\section{Despre articol}

Istoric:

Primit 4 decembrie 2015

Acceptat 13 ianuarie 2016

Publicat 1 august 2016

\section{Cuvinte-cheie:}

normă literară

lexic neologic

adaptarea fonetică și morfo-

logică a împrumuturilor

\begin{abstract}
Rezumat
Traducerea de la 1816 efectuată de Petru Maior, insuficient studiată, ne oferă un material prețios în privința normelor limbii literare din Transilvania primelor două decenii ale secolului al XIX-lea. Ne-am concentrat atenția asupra trăsăturilor fundamentale ale limbii literare, fără a scăpa însă din vedere nici trăsăturile secundare care ni s-au părut relevante pentru norma promovată de cărturarul ardelean. Se observă că materialul lingvistic extras din această traducere reflectă, pe lîngă normele fonetice și morfologice specifice graiului autorului, și norme stabilite după alte criterii decît cele ilustrate de tradiția locală, și anume criteriul apropierii de etimonul latin sau de norma muntenească promovată de tipăriturile religioase de la mijlocul veacului al XVIII-lea. În ceea ce privește lexicul neologic utilizat în această traducere, $s$-a realizat o clasificare semantică, urmărindu-se atît vocabularul de cultură generală, cît și lexicul de specialitate (terminologia medicală). Terminologia medicală a textului a fost prezentată pe cele două coordonate constitutive: cea cultă, neologică și cea de tip popular, tradițional. Au fost examinate și cele mai importante aspecte ale adaptării fonetice și morfologice a împrumuturilor, observîndu-se numărul ridicat de împrumuturi corect integrate, datorită orientării latino-romanice a cărturarului, dar și ponderea însemnată a variantelor fonetice analogice și a termenilor neadaptaţi (latinisme și italienisme).
\end{abstract}

\section{Introducere}

A doua jumătate a secolului al XVIII-lea și primele două decenii ale celui următor aduc o diversificare fără precedent a scrisului românesc. Textul de popularizare ce ilustrează diverse domenii ale științei (lingvistica, geografia, istoria, medicina, matematica, filozofia) ocupă un loc aparte în literatura epocii. În această perioadă, primatul cultural este deținut de cărturarii ardeleni care elaborează texte științifice originale, autentice, dar care, în același timp, desfăşoară o asiduă activitate de traducere și adaptare a numeroase texte de popularizare a științei.

Petru Maior este traducătorul mai multor cărți de știință popularizată ${ }^{1}$ prin care a contribuit atît la ridicarea nivelului cultural al cititorilor săi, cît și la dezvoltarea limbii române literare. Acest text de medicină veterinară tipărit la Buda în 1816, cu titlul complet Învățăturăpentru ferirea și doftoria boalelor celor ce se încing prin țeară și acelor ce se leagă și a unor boale sporadice, adecă pe ici, pe colo îmblătoare ale vitelor celor cu coarne, precum și a cailor, a oilor și a porcilor (130 de pagini), tradus, probabil, după un original maghiar, a apărut într-o perioadă însemnată din dezvoltarea românei literare și ridică mai multe probleme ce se cer studiate. Scrierea conține o serie de fenomene lingvistice (fonetice, morfologice și lexicale) importante pentru istoria normelor limbii române literare la început de secol XIX. De asemenea, fiind primul nostru text de medicină veterinară, acesta aduce o contribuție specială la dezvoltarea limbajului medical românesc în special și la modernizarea vocabularului literar în general.

*Adresă de corespondență: lilianasoare2006@yahoo.com.

${ }^{1}$ Vezi, în acest sens, Ursu (1961 și 2012). 
În lucrarea de față ne-am propus să surprindem configurația limbii literare folosite de P. Maior în această traducere, prin relevarea particularităților fonetice, morfologice și lexicale.

\section{Normele limbii literare}

În ceea ce privește norma literară promovată de P. Maior în această traducere, am consemnat următoarele fenomene:

- conservarea lui ă protonic în: lăcuința (119), năsipos (45), păhar (54), păreții (53, 126), rădicate (8).

- menținerea lui î etimologic: îmblare (3), îmblă (20,33, 36, 54, va îmbla, 23), imblătoare (f.t.), se îmflă (56, imflată, 27, dar se desumflă, 78), imflături (70), a se implea (13, le implu, 18, le imple, 11, 12, 24, să se imple, 117, nu s-au implut, 55), a întra $(37,43)$ etc.

- $r$ etimologic este păstrat în serină (3).

- conservarea lui $e$ aton etimologic în: strein (29, streine, 31, 127), instreinarea (100).

- conservarea lui $e$ protonic în beserică (19) și a lui $e$ medial în: a ceti (127, dar prociti, 127), cetitoriule (127), intunerec (129).

- e păstrat în detorie (115), detoriu (30,31, 50, 116).

- menținerea formelor etimologice fără $i$ epentetic: cînească (100), cîne (102, cînele, 102, cîni, 107, cînii, 46 etc.), minile (36).

- $i$ nesincopat are o singură ocurență: dirept (12). În rest, apar forme sincopate: $\operatorname{drept}(6,18,24,128)$, dreapta (130) etc.

- menținerea africatei prepalatale în: cricimă (36, cricime, 19), s-au obicinuit $(4,48,109,111)$.

- ia păstrat: descuiarea (66), iaste (22), încuiarea (66, dar încuierei, 67), miare (47), muiarea ( pieilor, 44), pialea (60), pricinuiaște (62), pustiaște (22), tăiare (37), voiaște (129) etc., dar pietră (53).

- ea final păstrat: a avea (37, vor avea, 66), ca să bea (65), prea (8, 13, 23 etc.), s-ar vedea (37) etc.

- jeste general: ajunge (27, 84, nu ajung, 67, ajungă, 37, de ajuns, 38), joacă (73), judecători (29, judecătorii, 31), judele (42, judelui, 39), județ (72), jumătate (67), imprejur (35, imprejurul, 99), imprejurare (56), injugătură (35) etc.

- africata $\breve{g}$ este păstrată în formele verbului încunjura: se incungiură (110, să se încungiure, 89, 95, să poată încungiura, 107), incungiurate (41, ne-ncungiurată, 88) și în: gios (13), prilegiu (107, prilegiul, 40, 48, 58), prilegiuitoare (105).

- $r$ moale: crepate (77), crepătura (80, crepături, 92), intrebuințarea (122), rece (65), strimte (94), strimtorat (30, strimtorați, 23, 35), stringătoare 'astringent' (51), strinse (18), strinsuri (81), îl uresc (25) etc. alternează cu $r$ dur: deoarăce (15), întrăbuința (119), lăcrămoşi (25), prăsărat (32, 114), prățul (112), putrăd (94, putrăde, 27), răce (65, răci, 64), rătrași (26), răvărsarea (82), trăbuie (21), trăbuință (118), trămura (104) etc. Timbrul palatal al vibrantei $r$ este redat cu consecvență și în cuvintele derivate cu sufixul -tor sau în cuvinte nederivate: ceriul ( gurei, 72), cuptoriul (109), curătoriu (117), muşcătoriu (110), necuvîntătoriu (3), păzitoriu (39), perzătoriul (105), vătămătoriu (6), viețittoriu (62) etc.

- $t$ dur alternează cu $t$ moale: tîmp (31, tîmpul, 31), timp (102, timpul, 33, 58).

- fonetismele cu $s, j, z, t$, duri: asămănare (55), să se cosască (9), încățălat (61), se încăţălează (92), a se însămna (109, însămnăm, 12), însătat (102), înțălepție (95), ințăles (12, ințălesul, 32), săci (92), sămnul (27), sîmțire (3), său (subst., 36), țapeni (103), țăpenirea (55), umezălei (lipsa , 78), zamă (51, zămuri, 123) etc. coexistă cu cele moi: curățitoare (90), despărțit (32), se increțește (96), ințelepțtește (127), lincezeala (81), părăsească (42), pedepsească $(29,40,49)$, să o preseri (120), să se procopsească (129), sinurile (88), slujește (111), se țin (30), umezelilor (100), se urzește (72) etc.

- ş. moale: s-au aşezat (35, aşezate, 25), deșeartă (adj., 124), să-i împărtăşească (24, impărtăşsesc, 118 , impărtășeşte, 20, 100), a o inșela (48), inșelători (49), pășeşte (104), sfîrşește (81), stropșeală (109) etc.

- $j$ dur: să o grijască (33), grijă (8) alternează cu j moale: să se grijească (38), mînjească (126), năcăjiți (107), slujeşte (111) etc.

- labiale intacte: ferbinţeală (110), a o impedeca (110, impedecă, 124, împedece, 104, 105), împedecări 
(18), peile (116), pelița (87), a-ipeptăna (108), va peri (70), perit (15, 106 perite, 46) etc., dar și forme palatalizate: fierbîntătoare (113), fierbințeala (7), fiert (84), impiedece (60), impiedicată (81), piept (51), să o pierdem (21), pierzătoare (23) etc.

- folosirea grupului consonantic $g l$ în locul palatalei, din dorința apropierii grafice de etimonul latin: priveglearea (44), veglearea (44), dar: să priveaghe (72).

- folosirea formelor regionale cu rostirea moale a labialelor: beşică (27), au beut (33), beutului (111), beutură $(49,60,106)$, capet (34, capetul, 70, dar capăt, 72), ovesul (3, dar ovăs, 123), proaspet (121), se ved (55, dar se văd, 66) etc., din dorința de a reduce cît mai mult frecvența vocalelor fără corespondent în latină $\breve{a}$ și $\hat{\imath}$.

- fonetismele cu $r$ conservat: ferestrile (43), ferestri (43), coexistă cu cele cu $r$ disimilat: fereștile (54).

- $f$ conservat: fier $(51,115)$, fiere (27) etc.

- $e>i$ în crieri (82).

- u>oîn: aborul (73, dar aburoase, 90), notreț $(38,50)$, poroncească $(29,36$, darporuncita, 130), răotăţile (130), răotățit (61), totoş (12).

- $f>v$ în: jertveşte (41), în vîrv (73, vîrvului limbei, 111).

- ş> > s, prin diferențiere consonantică, în: să se deschidă (54), deschişi (103) etc., în ciuda faptului că norma literară presupunea păstrarea fonetismului etimologic şîn deşchide (< lat. discludere).

- $a>a ̆$ : tăbac (119).

- l'în feliu. Maior folosește exclusiv forma palatalizată a acestui substantiv (< magh. féle).

- Substantivul soartă este folosit la forma veche, de declinarea a III-a: soarte (aceeaşi , 28), iar gingie apare cu forma impusă în limba literară: gingii $(73$, gingiile, 72,73$)$.

- La genitiv-dativ, unele feminine de declinarea I și a III-a prezintă încă vechea desinență -ei: beuturei (123), cercărei (40), curățirei (126), gurei (19), inimei (123), grijei (116), ivirei (26), incuierei (67), limbei (73), mîncărei (123), primăverei (72), putrăzirei (51), rumegărei (54), trecerei (43), turbărei (117), vindecărei (60) etc.

- Se constată lipsa acordului la cazurile oblice în construcțiile în care adjectivul este antepus substantivului pe care îl determină: asupra gangrenoasei înflamație (65), carnea trucidatei vită (80), causa sau pricina zisei boală (73), grosul întunerec al urîtei neștiințăa (129), pierzătoarei boală (48), proprietariul trucidatei adecă a ucisei vită (41), trucidarea sau uciderea contăgioasei vită (42), preservative sau scutitoriu asupra pierzătoarei boală (48), slăbiciune prea mare a bolnavei vită (51) etc., dar și în cele în care adjectivul este postpus: lățirea boalei contăgioasă (21), uciderea vitei contăgioasă (40) etc. Cazurile în care se realizează acordul sînt extrem de rare: răsuflarea vitei contăgioase (19).

- Formele variabile ale mărcii posesiv-genitivale sînt cel mai des utilizate: boalele contăgioase ale vitelor (21), imflatele picioare ale vitei (80), mortul al ei trup (32), oricarele al lor notreț (43), părți ale trupului (70), semne ale ivirei boalei de vite (26), schimbările cele fără cumpăt ale morbului (68), sinurile nărilor ale fălcei ceii din sus (88) etc. Formele invaribile ale mărcii posesiv-genitivale sînt slab reprezentate: cele mai sănătoase a vitelor bucăți (12), cumplitul a vieții rişchiu (104), stricatul aer a staurului (62), a vieței moment (125).

- Genitiv-dativul articolului adjectival este, la feminin singular, cei( $i)$, formă etimologică (<ecce + illei), și nu celei, formă analogică, după plural: atingerea vitei ceii cu boală contăgioasă (19), descărcarea materiei ceii morboasă (74), dreapta osîndă a slugei ceii vicleană (130), îmflătura partei ceii pătimicioasă (78), se împutăpăşunei ceii umedă și băltoasă (73), materiei ceii de scabie (94), scăderea pășunei ceii bună (61), semnele spiței dintîi adecă a ceii uşoară (101), vitei ceii dintîi contăgioasă (40) etc.

- Superlativul adjectivului/adverbului este construit cu prea, trăsătură specifică limbii vechi: căldura cea prea mare a verei (8), măcar că sînt prea sănătoase (12), prea contăgioasa boală de vite (22), slăbiciune prea mare a bolnavei vită (51), prea mare cruderitate (125), prea străluciților romani (127), prea bun părinte (129) etc. dar și cu foarte: pînză de in foarte subțire (16), fumegarea foarte bine se face cu oțet (54), foarte curînd (56), de foarte rău semn (57), foarte bună preservativă sau apărare (65), foarte cu de-adinsul prescripții (53) etc. 
- Folosirea formelor neacordate ale pronumelor de întărire se încadrează în norma epocii: însăşsi coarnele (19), însuşi oamenii (21), însuşi cei mai puternici moștenitori ale largilor moşii (23), însuşi de multe ori pierzătoarea boală (48) etc.

- Genitiv-dativul demonstrativului feminin de apropiere are forma aceștei la singular: asupra aceștei pierzătoare boală (28), intru prefacerea aceştei cărticică (127) și acestor la plural: acestor vite (66).

- forme variabile ale pronumelui relativ: carea (9), carele (32), carii (19) etc.

- Pronumele (adjectivele) nehotărîte compuse cu fiește-: fieștecare (30), fieștecarele (31), fieștecăria ( vită, 67), fieștecine (118) etc. și ori- / oare-: oarecarele (114), oarecîtva (42), oareșce (37, 92), orice (117), oricarele (112) sînt frecvente. $\mathrm{O}$ apariție singulară consemnăm pentru niscari $(\sim$ operații, $110<$ lat. nescio qualem), folosit ca adjectiv.

- Pronumele negativ nimic apare exclusiv sub forma nemica (< lat. nec mica, 26, 102, 112, 115 etc.).

- Numeralul colectiv amîndoao (86, amîndoi, 86), întîlnit în toate variantele literare și în toate graiurile, este dublat de îmbe $(86<$ lat. ambe), formă utilizată doar în zona Banat-Hunedoara și în unele graiuri nordice.

- folosirea exclusivă a formei cu hiat etimologic în formele verbului primi: a priimi (30), să o priimească (33), priimit (129) etc.

- utilizarea exclusivă a formelor verbale cu dentală refăcută: le ard (51), pot să cadă (60), să se inchidă (38), să se radă (53), să se scoată (53), să sloboadă (50), se văd (64), să se vîndă (46) etc.

- Verbele a rămîne și a ține sînt folosite la conjugarea a II-a etimologică, formă conservată mult timp în perioada veche: de a rămînea $(31,51)$, să poată rămînea $(41)$, vor rămînea $(70)$, le va ținea $(8)$, a le ținea (40), a-i ținea (108), se vor ținea (43) etc.

- tendința de trecere a verbelor de conjugarea a III-a latină în -ere la conjugarea I: se va adauge (68, se adauge, 102), să se adaugă (99), cură $(56,86,103)$, să poată cură (70).

- a se însănătoși apare încadrat la conjugarea I: se va însănătoșa (39), celor ce se însănătoașă (69), cu prezent tare.

- Verbul de conjugarea I a înconjura (terminat la infinitiv în -(ur)a) prezintă forma etimologică paroxitonă cu $u$ în silaba finală la prezentul indicativului și al conjunctivului: se incungiură (110), să se încungiure (89, 95), să poată încungiura (107) etc., precum și la participiu: încungiurate (41), nencungiurată (88).

- utilizarea formei negamatizate a verbului a ucide: să se ucidă $(32,40)$, în situația în care formele gamatizate erau încă frecvent întrebuințate în perioada elaborării textului.

- a înștiința (34), care este construit și cu dativul (să se înștiințeze superioritatei, 117), apare extrem de des înlocuit de locuțiunea verbală a face (de) știre (115): să facă de știre (30), să facă știre (33, 34, 116), vor face știre (34), va face știre (39) etc.

- a mînca apare, de regulă, folosit cu forma scurtă, specifică graiurilor ardelenești: mîncă $(25,87)$, să mînce (123), dar cunoaște și o ocurență cu forma lungă, etimologică: mănîncă (66).

- a usca prezintă forme cu sincopa lui u: să se uște (53), să-l uşte (126). Sincopa lui u se întîlnește și în cazul verbului înfrumuseța: $i$-au înfrumsățat (128).

- Verbul (re)curăța: să se curăță (109), să se răcurățe (115, să se răcurăță, 126) prezintă și o formă în care africata (asimilată formelor muntenești iotacizate) este înlocuită cu dentala, probabil din hipercorectitudine: să se curătă $(7,8)$.

- Verbele a dormita, a micşora, a urma au forme tari de prezent: urmă (21), se micşoară (106), dormită (103). Formă tare, fără sufix, caracteristică graiurilor nordice, prezintă și verbul a lucra: să se lucre (121).

- Perfectul compus prezintă, la singular, forme omonime cu pluralul, forme etimologice folosite exclusiv în toate variantele literare din româna veche: această boală pierzătoare au luat începutul său (23), prin contagiu s-au adus la oi (23), care vită s-au vindecat (24), stricătoarea boală de tot s-au așezat (35), vita carea au căzut de boală (37), iară de s-au ivit boala de vite (38), locul unde s-au ivit boala de vite (40), după ce au curs dintr-însa sîngele (120) etc. 
- Viitorul este, de regulă, construit din auxiliar și forma de infinitiv a verbului: se va avea grijă (89), vor avea (66), se vor incungiura (89), se va sugruma (82), va ști (61), se vor ținea (90), se va vindeca (60), vei întărîta (101), se vor întrăbuința (119), se vor vesti (91) etc., cu o singură excepție: (gangrenei) ce va se urme (80), formată din auxiliar și forma de conjunctiv a verbului.

- Condiţionalul prezent analitic are structuri formate din auxiliarul ar + infinitivul verbului de conjugat: s-ar adeveri (40), s-ar bolnăvi (34), s-ar cădea (29), s-ar doftori (96), s-ar ivi (34), s-ar pricepe (112), ar scăpa (115), ar veni (115) etc. Cele formate cu auxiliarul are nu sînt frecvente: are fi (112); s-ar bolnăvise (40) poate fi o formă de condițional perfect.

- Preferința lui Maior pentru folosirea infinitivului lung, în continuu regres în perioada respectivă, este evidentă ${ }^{2}$ : timpul cel rău a-l schimbare in bun (6), spre a se abate și a se scuti de fierbințeala soarelui și spre a se hodinire (7), mai vîrtos se cade a avere grijă de adăpare (8), se cade a luare aminte (9), acele animale sau vite care de aiurea moștenesc ceva întocmire spre a primire unele boale (18), inceată de a rumegare (26), inainte de a se puteare împlini (41), etc. Aceste structuri coexistă cu cele în care se folosește infinitivul scurt: încep a boli (18), sînt strimtorați a simți (22), despre primejdia răului timpuriu a-i înștiințta (34), ar cuteza a păşi (39), de a curma boala (40) etc.

- Formele de infinitiv, mai bine reprezentate numeric, coexistă cu cele concurente de conjunctiv: vor fi detori a face de știre (50), fieștecare ar fi detoriu de orice pagubă prin cînele său cel turbat acășunată a răspunde (107), trăbuie a-i sta în coantră (35), cel ce va cuteza a face (36), să li se dea adeseori a linge sare (58), iaste op a descoperi causa (105), iaste op adecă lipsă a împuțina numărul cînilor (106), mai rar poate acest rău a se esca (106), întru acest chip spre mînie a se intărîta (107), se cade a se osărba (107), se poate mînca (80), va fi strimtorat a face (106), vor trăbui a-l păți (124), idrofobia adecă boala carea face a se îngrozi de apă (109), sub ferbințeala soarelui a se stămurare adecă a se întețire (110), cine cuteză a-l doftori (113), carele va ști lucra (118) etc.; e detoriu [...] să facă de știre (30), e detoriu să-și țină vitele (31), toate cele mai sus zise cautele adecă feriri cu de-adins trăbuie să le țină (33), trăbuie să li se poroncească (36), nu poate să vină (112), trebuie să se arunce (118) etc.

- adverbe și locuțiuni adverbiale: adeseori (60), aliurea (42, de , 115), de aiurea (18), aliuntrea 'altminteri' (87, aliuntre, 117), altmintrea (71), amînat 'tîrziu' (73), amus 'acum' (102), cu de-adins (9), jur-împrejur (121), din lontru (27), încătrău (30, 31), incoace și încolo (101, 103), intr-aiurea (12), într-o lături (118), lungişş si curmeziş (21, 114), oblu (19), pe ici, pe colo (25), pre alocurea (22), tomna 'tocmai' $(37,101,102)$, mai vîrtos (44) etc. Semiadverbul nici este utilizat exclusiv sub forma nice (31, $52,68,108$ etc.).

- Prepozițiile prezintă fonetisme vechi sau regionale: cătră (7), dintră (39), întră (11), pănă (7), pre (24), preste (3), subt (29, supt, 6) etc. Spre este folosit și cu sens final ('pentru, în vederea'): spre a se abate (8), spre a se hodinire (8), spre a primire (18), spre acest scop (45), spre apărare, spre ferire, spre scutire (46) etc., iar fără și cu sens adverbial ('decît'), sens învechit: nu se ved altele fără încuiarea pîntecelui (63).

- Conjuncțiile dar și iar apar exclusiv folosite sub forma dară, iară; sau este general, forma veche au nefiind utilizată decît extrem de rar: pot după 20 de zile de la încetarea boalei au să se vîndă, au spre us, adecă întrebuințarea de casă să se întoarcă (46).

- Există mai multe cuvinte și fonetisme specifice scrierilor lui P. Maior, pe care le regăsim și în textul cercetat: forma atînt $(38,43)$, care, uneori, apare în corelație cu cînt 'cît': atînt a stäpînirei cînt a supuşilor (43). Atînt poate fi justificată atît prin influența dialectului aromân, cît și prin cea a limbii italiene. Însă este și posibil, după cum observa Ursu (1961, p. 139), ca Maior să fi refăcut, în spirit etimologist, formele vechi atît și cît prin raportare la latină (tantus, quantus) ori italiană (tanto, quanto); forma esca a verbului isca: se escază $(25,94)$, mai rar poate acest rău a se esca (106); calcul alsăuire 'proprietate, însuşire' (18), pe care îl folosește și în alte scrieri ale sale; alături de acesta, apare și calcul încetățenit în limba literară: însuşire (24); fonetismul coantră pentru contra (a-i sta în coantră, 35, stă în coantră, 65,

${ }^{2}$ Micu \& Șincai (1780) afirmau: „Poporul în convorbiri obișnuiește să omită ultima silabă re a infinitivului prezent și, în loc de a lăudare, a tăcere, a dormire etc., spun a lăuda, a tăcè etc.”' (51). 
din coantră, 3, 82); substantivul op 'trebuință, necesitate' $(10,38,106)$.

- Potrivit concepției sale că limba română literară trebuie îmbogățită și cu împrumuturi din aromână P. Maior folosește și cîteva cuvinte din acest dialect: se agudește (g. se intîmplă, 70), cîştiga 'grijă' (6, 30), demînda 'porunci' (29), plasă 'fel' $(6,12,59,112)$, pleaga 'rană (69), să se pleguiască (70), puştlă 'ciumă, pestă' (22).

- Tot pe seama influenței dialectului macedoromân poate fi pusă prezența formelor cu a protetic: acășunată (pagubă $\sim, 107)$, o acăşsună (61, dar căşună, 87), acrescută $(85,86)$, adoita (60), amişcată (77), aroade ( peliț, 87 ), aroasă (pînă la os $\sim, 88$, aroase, 88 ), se va asparge $(125)^{4}$.

- frecvența cuvintelor derivate cu prefixe: se dezvînă (62), incurăţirea (67), încurgere (3), necurățitele (3), necuvîntătoriu (3), neființa (3), nehodină (102), negrijă (22), prezisele (110), străsuflat (96, străsuflate, 3,43 ) etc. și cu sufixe: apărătoare (21), apătos (120), aprinsătură 'febră' (83), (rane) cancroase (87), pătimicioasă (78), pişcătoare $(87,92)$, rozitoare (92), (mîncătură) scărpinătoare (92), slobozitoare (68), tristăciune (78) etc.

- Se remarcă și folosirea unor cuvinte fără prefix: se va bolnăvi (32), călțămintele (36), se va cerca (54), cercărei (40), să se junghie (80), nainte (34), tuse necăcioasă (26), sănătoșare (83), se spăimîntă (103), țăpenirea (55).

- prezența unor termeni din latină dipăruți sau păstrați doar în graiuri: arină 'nisip' (119, arinos, 45 < lat. arena), să se astruce 'a înmormînta' ( 40 < lat. *astruicare < astruere), cătinel 'încet, lin, domol' (64, $104<$ lat. ${ }^{*}$ cautelinus), (semne) chiare $(117<$ lat. clarus, $-a,-u m)$, curechi $(122<$ lat. coliculus $)$, custă 'a trăi' (59 < lat. constare: mare parte a oilor fără de vărsat custă toată viața; poate mult să custe, 87), fărina ( 43 < lat. farina), junepru 'ienupăr, brădișor' (61 < lat. juniperus), a se la 'a se spăla' $(51,54,74$ < lat. lavo, -are), lard 'slănină' ( 93 < lat. lardum: puștelele curînd se încățălează și se prefac crustă adecă scoarță sau piele de lard, lardică, 93: pielea se acopere cu scoarță lardică), moare 'zeamă acră de varză' (122 < lat. muria), morsicat 'mușcat' $(124$, morsicată, $118<$ lat. morsicare).

Limitîndu-ne la trăsăturile fundamentale ale normei literare, principalele particularități ale limbii folosite de P. Maior în această traducere sînt: păstrarea lui ă protonic (păhar, păreții, rădicate); menținerea lui $\hat{\imath}$ etimologic (îmfla, îmbla, implea, întra); folosirea formelor etimologice fără epenteză (cînii, mînile); ia păstrat (pricinuiaște, pustiaște); ea final păstrat (avea, bea); $f$ conservat (fier, fiere); $j$ exclusiv, cu puține excepții (folosirea africatei în formele verbului încunjura: încungiura și în gios, prilegiul); ş moale (înşela, sfîrșește); $r$ moale în poziție finală în cuvinte nederivate: ceriu, cuptoriu, precum și în cele derivate cu -tor (curătoriu, necuvîntătoriu, păzitoriu, viețuitoriu); labiale moi (beșică, beutură, ved); forme variabile ale pronumelui relativ și ale mărcii posesiv-genitivale; auxiliarul au la persoana a III-a singular a perfectului compus; forme verbale cu dentala refăcută; prezența unor termeni din latină dipăruți sau păstrați doar în graiuri, precum și a unor cuvinte din dialectul aromân.

În celelalte situații, ne întîmpină oscilația în folosirea formelor velare sau moi: $r$ moale și velar (rece, răce); $t$ moale și velar (timp, tîmp); s, j, z,ț moi și velari (părăseascăa, sinurile, țin, umezelilor, grijască, ințtăles, săci, umezălei); labiale intacte sau palatalizate (ferbințeală, impedecă, fierbințeală, impiedecă).

În general, P. Maior folosește formele și fonetismele regionale, dar, în unele cazuri, rămîne aproape de norma literară muntenească promovată de tipăriturile religioase din a doua jumătate a secolului al XVIIIlea: $\breve{a}$ netrecut la $a$, ea final păstrat, labiale moi, $j$, amestecul de ș, $j$ moi și duri, labiala $f$ nepalatalizată, fonetisme cu $e / i$ sincopați etc. Cărturarul păstrează unele fonetisme muntenești în măsura în care acestea erau capabile să redea forma etimoanelor latinești (de pildă, fonetismele cu $j$ erau preferate pentru că redau mult mai exact imaginea grafică a cuvintelor latinești corespunzătoare: joc < jocum, judeca < judicare; în verbul încungiura, Maior folosește, din aceleași considerente, africata $\breve{g}$ : < $\hat{\imath}$ + lat. congyrare; deși formele verbale cu dentala iotacizată erau cele etimologice, Maior le respinge, preferînd inovația, formele cu dentala

\footnotetext{
${ }^{3}$ În postfața traducerii, Maior afirmă: „...întru prefacerea aceștei cărticică m-am întrebuințat cu mai multe dialecte ale limbei românești, din carele unele nu sînt astăzi cunoscute în patria ta...” (127).

${ }^{4}$ După cum observa Ursu (1961), unele dintre formele menționate nu au corespondent în dialectul aromân. Pe acestea, autorul le-a creat probabil prin analogie cu cele aromâne sau italiene (cf. it. accréscere, aspérgere) (p. 138).
} 
refăcută, mult mai apropiate grafic de etimonul latinesc).

Limba literară promovată de Maior în această traducere este o limbă ce are ca punct de plecare norma literară muntenească din perioada 1750-1780, dar care integrează și graiurile ardelene și bănățene. Examinînd normele limbii literare din mai multe scrieri elaborate de cărturarul ardelean, Gheție (1975, p. 484) opina că acesta trebuie considerat creatorul normei literare ardelenești din jurul anilor 1820, prima încercare deliberată de a structura limba româna literară pe baza unei selecții a limbii scrise și vorbite, urmînd un criteriu unitar.

\section{Clasificarea semantică a lexicului neologic cult}

În ceea ce privește lexicul neologic, termenii culți excerptați din textul cercetat aparțin unor domenii semantice variate; aceștia acoperă, într-o pondere diferită, sferele vieții spirituale și materiale. Devine posibilă astfel o clasificare impusă de frecvența și de sferele semantice cărora aparțin acești termeni:

\subsection{Termeni referitori la om}

- atribute, însușiri: acurata (48), amoniți 'admonestați' (39), ample (65), aromatice (108, 123), complicată (82), comună (61, comuna, 31), continue (81, 84, 122), contrarii (22), corupt (94, coruptul, 62), crispă 'creață’ (lînă , 92), cristalin (57), cruderă (125), denudata (99), depravate (plämînile, 82), destinatul (a., 45), diretive (21), diversă (55, diverse, 19, 21), ermii 'pustii' (107), fals (95, falsă, 95, 110), fatal (124, fatală, 81, fatalul, 34), fluid (117), fosta (78), frigidă (84, 108), funestul (105), generale (21), genuin (96), indiferent (102), liber (65), manifestă (adj., 34), mordac 'mușcător' (110), munde $(64,85)$, necesarie $(32,105,108,116$, necesarii, 107), necorupt $(108)$, nocivă $(71$, nocib, 109 , nocibe, 107), nudă $(71,93$, nude, 71, 115), nutritoare (50), ocasionale (105), parțiale (5), pendente 'care atîrnă' (îmflătură , 82, g. adecă atîrnată, spînzurată), politicești (30), politico-veterinarii ( disposiții, 104), prescriptul (adj., 32), profondă (63), proporționată (68, proporționate, 65), propria (42, 117), prostrată (63), prudent (95), publica (113), remot 'îndepărtat' (32, 46), repețita (59, 60), robuste (62), sapidă (95), săturat 'saturat' (84, 85), scutită (41), segregată (33), cea mai segură (112), separat (32, 40, separată, 80, separate, 31), simplă (60), spise 'gros' (73), sporadice, (f.t.), subsit (27, subsite, 36, 71), tepidă (69), trucidatei (41), vaporoasă (94), văciliți 'vacilant' (73), veget (87, vegetă, 68), (apă) vegetominerală $(69,80)$.

- acțiuni, fenomene, stări, atitudini, manifestări, sentimente, obiecte: acrimonia (100), amînare (36), atmosfera (53), aversația (63), causă $(12,37)$, cautela 'precauție, prevedere' (125, cautelă, 37 , 52, cautele, 33, cautelele, 13), cauţie (89), celeritate (63), cerc (56), coloră (56, 81, coloara, 92, 116, coloară, 100), cruderitate (125), custodie (39), damne 'daună, pagubă' (111), depunerea, (74), dialecta (128, dialecte, 127), diferență $(108,112)$, dirigență (108), distanță (34), esculente (g. bucate, 108), esempru (125, esempruri, 111, asempru, 41), faciritate (87), fenomene (83), forma (70), forța (74, cu , 39), foabă (g. groapă, 114), fosă 'groapă, accident de relief' (g. groapa, 41), gradu (86), materie (92), moment (125), moturi 'mișcări' (123), murii 'zid, perete' (53, 91), necesitatea (49), nutremînt (50,108, nutremînturi, 108), ocasia (111), oscuritate (63), penuria (61), periclu (74), periferia (37), periodul (87), personele (42), precauție (107), producturile (39, produturi, 19), public (35), răsfugarea 'emanație, evaporație' (83, răsfugările, 6, 25), regule (110, regulele, 21, 123), repurgația (g. curățirea staurilor, 52), sarcină 'responsabilitate' (116), scopu (38, 67, scopul, 89, scopos, 30), scrupul 'unitate de măsură’ (69), siguranță (113, siguranța, 41), speranță (83), sperare (125), speriință 'experiență’ $(24,82)$, spese (89, speselor, 32), sterc $^{5}$ (g. balega, 108), subsire 'moarte' (50), teritoriu (112), terminul (88, 101), tirănie (125), trucidarea 'uciderea' (41), us (46), violenției (110).

- acțiuni concrete, verbe dicendi, de mișcare etc.: se va acerăla (125), vor alăbora 'munci, lucra' (44), a amina (35), amonim 'admonesta' (111), avearsă / aversă 'a urî, a avea o aversiune față de' (101, 102,

${ }^{5}$ Sub forma șterc, cuvîntul era cunoscut în epocă; fonetismul sterc poate reprezenta un reîmprumut din latină și italiană (lat. stercus, it. sterco). 
104), să se cercete (112, să se cerceate, 91), a clăudica 'șchiopăta' (92), se comîndă 'a (se) recomanda' ('de veterinari se comîndă, 46), să se comită 'a se încredința' (116), să se continue (84, 122), decură $(63,64$, 93), a le deduce (39, să se deducă, 40), să se defalce (9), depende (74), să se descrie (116), să se dețină 'a împiedica de la ceva, a reține' (66), se devastă (23), devăgînd 'a rătăci, a umbla fără scop' (106), a devora (108), se devide (72,77), se diferesc (55), a se dimica 'a se lupta' (107, g. a se bate, a se mînca cu alți cîni), să nu se dimită 'a trimite, a lăsa să plece' (66), se impută (73), să încrustezi (80), vor îngurgita (107), să se înbume (113, 115), să se întărzică (44), să fie necesitați (108), nutri (90, nutresc, 3, se nutresc, 108, se vor nutri, 90), să obleagă 'a se îndatora, angaja' (6) ocură 'apar' (64), opoarte 'trebuie, se cuvine' (g. trăbuie, 125, 126), se oserbă (101, a se osărba, 107), să o pisezi (97), predespun (89), s-au prescris (115), preserba (113), produce (62), promove 'a mișca' (65), să se proveadă 'a înzestra cu cele necesare' (38), să-i rămoavă 'a îndepărta' (106), să se răpurge 'să se curețe' $(53,109)$, răsistă $(65)$, se răsoarbe (95, se răsorb, 100), răținîndu-se (40), să se repețească (68), să nu te scăndălisești (127), spera (88, a se spera, 74), subsește (45), vor subsi (64), se termină (81), să se trucide (80, să-l trucizi, 112), văcelindu-se (103), voluta (82).

- funcții, stări sociale, profesii, îndeletniciri, relații interumane: coloni 'țăran ce muncește un pămînt luat în arendă de la marii proprietari' (35), comunitate (39), custode (39), econom (95, economul, 89), magistratului (72), primorilor 'cei fruntași, de rang' (29), privaților (s., 31), proprietariu $(31,90)$, servitorii (44).

- instituții, administrație: $\operatorname{casa}^{6}$ (g. lada sau punga comunitatei, 41), poliţiei (36), de la superioritate (49), statul (110).

- comerț: comerciul (35), confiscației (43), contraband (43).

\subsection{Termeni referitori la natură}

- regnul mineral, vegetal; substanțe de origine minerală, vegetală: acid salis (50), acidi săturat (84), acidu vitrioli 'acid sulfuric' (85), sare alcală (89), arcan duplicat 'preparat de uz medicinal' (67), argilă (80), arsenic (89), auripigmentu (89), beladona (89), calam aromatic 'Acorus calamus, plantă erbacee cu utilizări în medicină $(69,89)$, calce 'oxid de calciu' (114), camfor (51), cascarila 'Croton eleuteria, arbust a cărui scoarță este folosită în medicină ca tonic și reducător al febrei' (76, cascarilăa, 97), cenuşă clavelată 'drojdie de vin calcinat' (89), cremortartari (67), emula 'plantă' (50), furfură 'tărîțe' (60), galanga 'plantă erbacee asemănătoare ghimbirului cu utilizări în medicină $(50)$, gențiana $(50,76)$, gumi de Arabia 'mucilagiu' (69), litarghiriu 'litargir, oxid de plumb topit și cristalizat' (79), minerală de Etiop (98), moshu 'mosc' (96), natura (128), savadilă 'plantă din familia liliaceelor folosită în tratamentul homeopatic al problemelor respiratorii' (pulbere de , 98), spirit vitrioli (84), tartar ametic 'tartrat de antimoniu și potasiu folosit în medicină ca vomitiv' (84), terebentină $(68)$, valeriana $(51)$, vanilă (97).

- regnul animal: animal (adj., 61, trupul ), animal (s., 119, animalul, 103, 105, animalelor, 116), animantul (64, animantu, 112, 118, 126, animante, 24, 77, 104, 105, animantele, 104, animantului, 103), copia 'mulțime, turmă' (6,21), cornută (29, cornute, 23, cornutelor, 22), domestice (36), generație 'prăsire' (95).

\subsection{Lexicul specializat}

- ramuri medicale, termeni generali, boli: corpul (87), disenteria (27, 51), doftoria (124), doftoresc 'medical' (cuvînt , 47), s-ar doftori (96), doftoritoare (21), inferma (80), lienita 'splenită (62), (cu) lienitidă (57), morb (81, 92, morbul, 68), morboasă (74), peripneumenia (57), prescriptul (32, prescripții, 53), scabia (94, scabiei, 94), scăbioase (93), idiopatică (77), pilule (97), remit 'a intra în remisiune' $(68,69)$, simptomatică $(77)$, simptome $(74$, simptomele 68,101$)$, urina $(63)$, veterinaria 'medicină veterinară (3);

\footnotetext{
${ }^{6}$ Calc semantic după it. cassa.
} 
- profesii, specialiști: doftor (119, doftorul, 121), hirurg (118, 119), personele cele doftoritoare (42), veterinariul (49, 91, veterinari, 13$)$;

- instituții medicale: lăzăret $(29,38,39)$, ospital $(32,34)$;

- anatomie: abomas 'foios, unul dintre cele patru compartimente ale stomacului rumegătoarelor' (27), astremități (70, astremitatelor, 63), cadabru (45, 82, 87, cadabrului, 37, cădabru, 32, 71), cadăbroasă (71, cădăbros, 72), corpul (87), duoden (27), limfei (82), membrana (88), mesenteriului (ghindurile , 88), muşchi (120), nervului tendinos (111), omas 'cheag, stomacul glandular propriu-zis al rumegătoarelor' (23), stomah (69), sudorifere (90);

- fiziologie: apetita $(55,63,68,69$, apetită, 101), circulația $(124)$,pulsu $(63,68)$, respirația (63), transpirația (21);

- simptomatologie: diarea (26,51), inflamația (77, inflamație, 65, inflămația, 61), înflămate (72, 73), inflămatorie (82), se intumesc 'a se inflama' (87), ostipația (66), ostruție (67), sufocativă (63), vomitu (84);

- farmacologie: antifloghistică (84, antifloghistice, 51, 84), decoct (51, 123), dosă (47, 69), emetic (s., 84), infus (52, infusu, 122, înfus, 69, înfuse, 67, înfusurile, 69), se va înstila (54), pastă (80), roborîtoare (69), stimulante (108);

- medicină internă: congestii (pl., 81), gangrenă (56,61), gangrenoasă (71, găngrenoase, 27, 82), hronice (86), se îngăngrenesc (28), metastatică (77), resoluția ( adecă desfacerea, descuiarea ostruțiilor adecă a incuierei, 67), schiroasa (86), suporința (85), supurație $(78,120,12)$;

- medicină preventivă: oculația (59), preserba (112), preservativă (s., $28,48,57,65$, preservative, 28 , 111), preservativ (adj., 46, preservative, 21), inoculația $(59,60)$;

- medicină curativă: clismă (122, clisma, 126, clismele, 84), curative (21), remediu (112, remediuri, 67);

- epidemiologie: contagiu $(11,94)$, contagios $(117$, contagioasa, 88, contăgios, 21), contaminate (91), ase contăgi (58), contumație 'carantină (29, 40, 52), epidemie (77, epidimie, 54), epidemic (88, epidemică, 61,72, 81), epizootică (13, epizootice, 13), (impedecarea) propagației (105);

- chirurgie: amputația (111), castrația (111), cauterisația (111), cauteriu (51), circumciderea (111), foarcepă (115), operații (110), să se scarifacă $(70,120,121,126)$;

- neurologie, psihiatrie, psihologie: deliriul (84), disposiție (66, 100, disposiții, 113, disposițiile, 38), idrofobia (109), melanhonie (101), titilație 'titilomanie' (92);

- dermatologie: cicatrice (121), crustă (92), pruringine 7 (92), prurit (92, 93, 121);

- otorinolaringologie, stomatologie: afte (72, 73, aftele, 74), angina (15, 81, 83), palatul (72).

Alături de împrumuturi, se regăsește terminologia populară. De regulă, cuvintele vechi sînt folosite pentru a glosa noii termeni: aprindere 'inflamație' $(23,57,60)$, 'febră (84), aprinsătură 'febră' (83), argint viu (99), va asuda (122), beșică 'vezică' ( cea de fiere, 27, cea de fiare, 82), beșicuțe 'afte' (26, 121), boală ( de gură, $\sim$ de picioare, $\sim$ de plămîni, $\sim$ de picioare sau de unghii, $\sim$ de plämîni $14, \sim$ de splină, $\sim$ de ficat 15, cea mucoasă a cailor, 17), bold 'instinct' (110, g. patima), brînca 'angină' (15), călbeaza 'boală de ficat' (15), ceriul gurei 'palat' (72), ciumă (22), cufureală 'diaree' (57), curgerea mucoasă a nărilor 'rinoree' (86), deșertare 'defecație' ( a șezutului, 122), foale 'abdomen' (66, 69), foc 'febră (84), frigurile (87), gînfarea 'inflamare' (63), se gînfă 'a se inflama' (87), ghinduri 'glandă' (88), inima rea 'dizenterie' (27), îmblarea sîngelui 'circulație' (124), încuiere 'constipație' (67, încuiare, 63, încuietură, 102), încurgere 'influență' (3), învechita 'cronică' ( boală, 87), jalie 'jalfie, plantă aromatică' (51), jugănirea (111), să se lățească 'a se propaga' (90), leacuri (36), lictariul (48), lîngoare 'febră tifoidă’ (57), lupariță 'boală' (87, g. rane cancroase), mațele (82), mațul cel gros 'intestinul gros' (27), mădulärile (70), mucu 'mucozitate' (86, mucii, 86), năcreală (43), obrintitură 'inflamație' (57), pătimaşul 'pacientul, bolnavul' (122), pelin (75), pelița 'membrana' (87), pișat (19), pişcătoare (87), rîia (17), puştea 'aftă bucală' (71, puştlele, 55), rînză 'stomac' (26), rută 'virnanț' (75), ruje (76), salce 'plantă erbacee cu utilizări în medicină' (89), salitră (60),

\footnotetext{
${ }^{7}$ Formă contaminată din prurit și pecingine (egzemă, herpes)? 'Rîia iaste boală de piele cu puștele sau beșicuțe săci [...] și e rău contagios cu oareșce pruringine, adecă mîncătură scărpinătoare împreunat'.
} 
sarea de piatră (65), scordiu 'iarbă-usturoasă' (75), scupit 'salivă (125), sgrăbunță 'rană' (71), sinurile 'sinus' (88), slobozirea foalelui (69), slobozire de singe 'flebotomie' (90), slobozitoare 'diuretice' (68), spiță 'stadiu' (103), 'tip, fel' $(57,100)$, stîmpărată (beutură , 60), stringătoare 'astringent' (51), strinsuri 'congestie' (81), terpentin (pop. 68, de Veneția, 99, oleu de , 99), trupul (87), turbarea (17), ud 'urină' (19), umezelilor 'umoare, fire, temperament' (100), unsoare 'unguent' (75, 97, unsătura, 99), vînturi 'flatulenţă' (26), vintricel 'stomac' (26), viţă 'specie' (100) etc.

\section{Adaptarea fonetică și morfologică a împrumuturilor}

4.1. Formele mai vechi de adaptare fonetică cu $t, g$, , și $k$ sînt aproape inexistente în textul cercetat: antifloghistică, litarghiriu. Acestea sînt concurate de variantele fonetice în $\breve{c}, \breve{g}$, care impun modelul latinoromanic al noilor termeni: celeritate, cerc, cicatrice, circulația, frigidă, general, generație etc.

Prin influența limbii italiene, respectiv prin influența grafică și fonetică a etimonului italian, pot fi explicate cîteva situații de adaptare a împrumuturilor, cum ar fi folosirea variantei neologice fără $b$ inițial: idrofobie și a următoarelor fonetisme: astremități (it. estremità), diretive (it. direttivo), melanhonie (it. malinconia), oscuritate (it. oscurità), se oserbă (it. osservare), ospital (it. ospedale), ostruție (it. ostruzione), personele (it. persona), produturi (it. prodotto), profondă (it. profondo). Și prin latină, pot fi explicate fonetisme precum: comerciu (it. commercio, lat. commercium), contagiu (it. contagio, lat. contagio, -onis) ori necesarie (it. necessario, lat. necessarius).

Formele cu $s$ (intervocalic) reflectă, în general, aspectul grafic al termenilor noi de proveniență latinoromanică (latină și italiană): cauterisație, disenterie, dosă, mesenteriului, ocasionale, preserva, spese, us etc. In ceea ce privește grupul consonantic $c h$, acesta este redat prin $h$ : hirurg, hronice.

În cazul lui roborittoare, avem un calc lexical de structură după fr. roborant. Din neogreacă provin

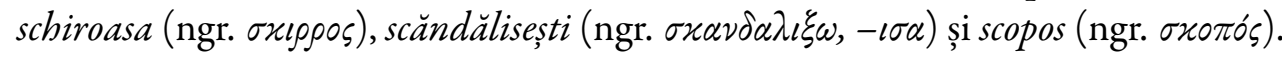

4.2. Variante analogice. Pe lîngă neologismele cărora li se aplică reguli moderne de adaptare fonetică, există și termeni cărora li se aplică legi fonetice de tip latin, suferite de cuvintele din fondul vechi al limbii.

\section{Vocalism}

- $a$ aton $>a ̆$, prin analogie cu termenii vechi moșteniți din latină sau împrumuturi vechi din alte limbi: cădabru, cădăbros, a clăudica, a se contăgi, contăgios, devăgînd, găngrenoase, inflämate, înflămatorie, inflämație, săturat, scăbioase, să nu te scăndălisești, tirănie, văcelindu-se, văciliți.

- $a$ și $e+n+$ consoană $>\hat{\imath}$ (inclusiv în sufixul -ment): se comîndă, nutremînt, nutremînturi.

- in-, inter- > în-, întră-/întăr-: îndiferent, înferma, înflamația, înfus, înoculația, să se întărzică .

\section{Consonantism}

- $v>b$ : cădăbros, foabă, nocib, osărba, preserba.

- $l$ intervocalic > r: se va acerăla, cruderă, cruderitate, dirigență, esempru', faciritate.

- $r e>r a ̆$ - prin analogie cu tratamentul lui re- în cuvintele latinești moștenite (răpune, răposa): să se răpurge, răsistă, se răsoarbe.

- ex- >s- (în virtutea regulii conform căreia $x$ intervocalic a devenit $s$, iar prefixele ex- și extra- au devenit $s-$, respectiv stră-: lăsa, măsea, strămuta, străpunge): esempru, speriință.

După cum se poate observa, fonetismele analogice au o pondere relativ însemnată. Acest lucru este o consecință firească a concepției care stătea la baza programului filologic inițiat de cărturarii ardeleni, primii care stabilesc reguli de asimilare a împrumuturilor și care oferă un model de referință în acest sens. Adaptarea în limba română a neologismelor de origine latino-romanică se caracterizează în scrierile lor prin tendința de a le supune acelorași transformări fonetice suferite de cuvintele moștenite. Acest proces de „românizare” a neologismelor, prin aplicarea, uneori sistematică, a legilor fonetice evidențiate de evoluția elementelor

\footnotetext{
${ }^{8}$ Fenomenul s-ar putea datora şi unei analogii între $i n$ - şi prefixul vechi $\hat{\imath} n-$.

${ }^{9}$ Poate fi și un împrumut direct din it. esempro.
} 
moștenite nu s-a dovedit a fi viabil (a fost folosit, totuși, pînă spre 1860); în locul acestor forme, evoluția ulterioară a limbii literare a reținut variantele ce demonstrează că „latina a exercitat prin fonetismul și formele ei [...] rolul de model, care a influențat elementele neologice împrumutate din limbile romanice [...]” (Munteanu \& Țâra, 1983, p. 255), și nu numai din aceste limbi, ci și din neogreacă, germană sau maghiară. Acest lucru deoarece, în contextul general european, împrumuturile din latină ce au dobîndit statut de cuvinte internaționale și-au menținut forma cît mai aproape de etimonul originar.

4.3. În ceea ce privește adaptarea morfologică, textul cercetat prezintă o caracteristică importantă (care este și a epocii): productivitatea deosebită a formelor cu -ie, de declinarea a III-a (vezi și Slave, 1962, p. 167). În vechea română literară, substantivele latinești de declinarea a III-a, terminate în -io, -ionis, sînt adaptate cu terminația -ie, după forma nominativului latinesc. Vechile împrumuturi substantivale în -ie, feminine și masculine, de sorginte veche slavă sau neogrecească, creaseră de timpuriu o normă de adaptare a terminației substantivelor, normă ce va fi ulterior generalizată și în cazul împrumuturilor latinoromanice.

Majoritatea substantivelor excerptate sînt feminine și sînt consacrate pînă astăzi în această declinare şi cu această terminație: amputație, cauterisația, circulație, generație, inflamație, (în)oculație, operație, ostipație, precauție, propagație, resoluție, respirație, supurație, transpirație etc. Unele sînt considerate astăzi învechite sau au ieșit din uz, fiind înlocuite de perechi substantivale, provenite din infinitive lungi: cauterizare, inoculare, propagare, supurare. Alte două cuvinte: aversație și titilație rămîn încadrate aceleiași declinări, dar s-au impus în limbă cu forme ușor modificate: aversiune și titilomanie. Culoare și vanilie apar încadrate la declinarea I: coloră/coloară, vanilă.

Substantivele neologice în -(i)tate, aparținînd declinării a III-a au corespondente latine în -(i)tas, -(i)tatis, germane în -(i)tät, maghiare în -(i)tas, italiene în-(i)tá, franceze în-(i)té: celeritate, comunitate, cruderitate, faciritate, oscuritate etc.

În textele perioadei, substantivele latinești terminate în -antia, -entia și, prin analogie, substantivele corespunzătoare de proveniență maghiară în -ancia, -encia, franceze în -ance, -ence, germane în -anz, -enz, italiene în -anza, -enza erau adaptate cu terminațiile -anție și -enție, de declinarea a III-a: audienție, corespondenție, diștanţie etc. În textul elaborat de către P. Maior, acest tip de substantive apar deja încadrate la declinarea I, datorită influenței limbii italiene: diferență, dirigențăa distanță, speranță.

Dintre substantivele neologice terminate la singular în -iu, de proveniență latino-italiană: cauteriu, contagiu, deliriu, mesenteriu, remediu, teritoriu doar ultimele s-au impus în limbă cu această terminație. Celelalte au fost reîmprumutate ulterior din franceză, cu forme fără diftong. Contagiu a fost înlocuit cu forma de declinarea a III-a contagiune.

Cîteva substantive neologice apar încadrate la alte genuri decît cele la care s-au stabilit ulterior. Se observă două situații: 1. încadrarea la neutru a unor substantive stabilite ulterior la feminin: contraband, infus/înfus, periodul; 2. încadrarea la feminin a unor substantive stabilite la neutru: apetita, dialecta, foarcepă, minerală, preservativă.

4.4. În ceea ce privește clasa adjectivului, se remarcă faptul că majoritatea împrumuturilor apar adaptate sub forma reținută de evoluția ulterioară a limbii literare: acurata, ample, complicată, contaminate, diversă, fluid, frigidă, genuin, segregate, veget etc.

În perioada de care ne ocupăm, cînd numărul împrumuturilor din diverse limbi crește simțitor, sufixul -icesc a servit la adaptarea în română, prin substituirea sufixelor corespunzătoare, a numeroase împrumuturi. În textele cărturarilor ardeleni, a căror cultură era predominant latină și germană, și care realizau numeroase traduceri în special din aceste limbi, mai toate adjectivele neologice au corespondente latinești în -icus, italiene în -ico, germane în -isch și franceze în -ique: analiticesc, colericesc, diplomaticesc, gramaticesc, loghicesc, metalicesc etc. În textul cercetat, există un singur adjectiv adaptat cu acest sufix: politicesc. În rest, datorită influenței latino-romanice, apar forme adaptate cu -ic, preluate ca atare, forme moderne, care s-au impus ulterior în limbă: antifloghistic, aromatice, epidemic, epizootică, idiopatică, metastatică, 
simptomatică.

În privința adaptării adjectivelor neologice provenite din adjective latinești în -alis, -arius și italienești în -ale, -ario, -are, P. Maior utilizează forme deja adaptate cu sufixele neologice corespunzătoare (-al, -ar), în detrimentul sufixelor specifice perioadei: -alicesc, -alnic, -aricesc și -arnic (vezi Ursu, 1969): fatal, general, parțiale.

Adjectivele derivate cu -iv (lat. -ivus, fr. -if, -ive, it. -ivo, germ. -iv) și -os (lat. -osus, it. oso, fr. -eux, -euse, germ. -ös) sînt numeroase, fiind adaptate de la început în această formă, datorită existenței în limba română a derivatelor de origine slavă cu aceste sufixe, respectiv latină: curativ, diretiv, nociv, preservativ, cu o singură excepție (nutritoare 'nutritiv', derivat cu sufixul vechi -toare); cădăbros, contagios/contăgios, gangrenoasă/găngrenoase, morboasă, scăbioase, tendinos etc.

Celelalte categorii de adjective neologice, terminate în -ant(e) / -ent(e) (adaptate după adjective de origine latină terminate în -ans, -antis, -ens, -entis, italiene în -ante, -ente, franceze în -ant, -ent, germane în -ant, -ent), -bil (lat. -bilis, it. -bile, fr. -ble), apar folosite de cărturarul ardelean, în marea lor majoritate, cu forma pe care o au și astăzi: indiferent, pendente, prudent, stimulante. Două adjective care aparțin acestei clase sînt adaptate cu alte sufixe: roborîtoare 'roborant' și văciliți 'vacilant'.

4.5. În privința clasei verbului, orientarea latino-romanică a autorului a făcut posibilă pătrunderea unui număr însemnat de verbe adaptate, urmînd modelul latino-romanic, la forma reținută de limba literară. Apar puține cazuri de încadrare la conjugarea a IV-a, cea mai productivă în perioada respectivă, în detrimentul conjugării I: a se contăgi, îngăngreni (se îngăngrenesc), a (se) repeți (să se repețească), scăndălisi (să nu te scăndălisești).

Extrem de puține verbe aparțin de drept conjugării a IV-a, respectîndu-se, și în acest caz, modelul latino-romanic: lat., it. -ere, -ire, fr. $-i r>$ rom. $-i$ : nutri, răsorbi.

Există situaţii în care anumite verbe sînt folosite fără sufixul flexionar: să se cercete/cerceate, se devastă, iar altele prezintă sufix: se diferesc.

4.6. În ceea ce privește adaptarea semantică, se observă utilizarea unor lexeme cu alte sensuri decît cele cu care s-au impus în limba literară: să se comită 'a se încredința', a devaga 'a rătăci, a umbla fără scop', a se dimite ( la păş̧une) 'a trimite, a lăsa să plece', generație 'prăsire', remit 'a intra în remisiune' (despre simptome).

4.7. Cuvinte neadaptate. Textul cercetat prezintă o pondere însemnată a lexemelor care nu s-au impus în limbă, cuvinte neadaptate sistemului fonetic și morfologic al limbii române ori cuvinte adaptate, dar care reprezintă împrumuturi personale ale cărturarului ardelean, datorate formației sale latino-romanice. În funcție de originea lor, acestea se grupează în două categorii:

Latinisme: abomas (lat. abomasum < ab + omasum 'măruntaie de bou'), vor alăbora (lat. laboro), animant (lat. animans, $-n t i s$ ), avears $\breve{a}$ / avers $\breve{a}$ (lat. aversor), copie (< lat. copia), crispa $\breve{a}$ (< lat. crispus), damne (lat. damnum), depende (lat. dependere), a se dimica (lat. dimico), să nu se dimită (lat. demitto, -ere), foabă (lat. fovea), furfură (< lat. furfur, -uris), se intumesc (< lat. intumesco, -ere), morbul (lat. morbus), mordac (lat. mordax, -cis), moturi (lat. motus), munde (lat. munde), murii (lat. murus) $)^{10}$, ocură (lat. occurro), omas (lat. omasum), opoarte (lat. oportet, -ere), periclu (lat. periculum), primorilor (lat. primoris), producturile (lat. productus), promove (lat. promoveo, -ere), să-i rămoavă (lat. removeo, -ere), remot (lat. remotus), salis (acid , lat. salis), spise (lat. spissus), subsire (lat. subsido, -ere), tepidă (lat. tepide), terminul (lat. termen, -inis), trucida (lat. trucido), trucidarea (lat. trucidatio), văcelindu-se (lat. vacillo), văciliți (lat. vacillatum), voluta (lat. voluto).

Italienisme: acidi (it. pl. acidi), amoni, amonit (it. ammonire), calam aromatic (it. calamo aromatico),

\footnotetext{
${ }^{10}$ Poate reprezenta și un împrumut din macedoromână (muru).
} 
cascarila (it. cascarilla), cautela (it. cautela), contumație (it. contumacia), ermii (it. pl. ermi) ${ }^{11}$, esculente (it. f. pl. esculente) ${ }^{12}$, galanga (it. galanga), să se proveadă (it. provvedere), răsfugările (it. risfogare), savadilă (it. sabadilla), veterinaria (it. veterinaria).

\section{Concluzii}

Limba literară promovată de Maior în această traducere este o limbă ce are ca punct de plecare norma literară muntenească din perioada 1750-1780, reevaluată din perspectiva latinismului și corectată cu o serie de fenomene specifice graiurilor ardelene și bănățene. Formele și fonetismele sînt alese în funcție de criteriul maximei apropieri de etimonul latin, ceea ce arată faptul că învățatul ardelean opera o selecție cu scopul creării unei norme supradialectale.

În ceea ce privește lexicul, se observă că fondul neologic al textului este grupat în jurul unei constante romanice (latine și italiene) care a contribuit la modernizarea evidentă a vocabularului românesc. Numărul ridicat de împrumuturi latino-romanice este relevant pentru apropierea cărturarului ardelean de cultura apuseană. Adaptarea noilor cuvinte este realizată atît în funcție de normele culte latino-romanice, cît și de cele vechi, analogice, criteriul apropierii maxime de etimonul latin fiind aplicat și în procesul de integrare a împrumuturilor, nu doar în selectarea anumitor forme și fonetisme oferite de graiuri. Majoritatea termenilor apar corect încadrați în sistemul limbii române; aceștia și-au dovedit utilitatea și viabilitatea, impunîndu-se în limbă chiar cu forma utilizată de autor. Relevante pentru orientarea occidentală a autorului (în sensul unei atitudini culturale asumate și nu a aservirii față de model) și pentru opțiunea acestuia privitoare la sursele de înnoire lexicală sînt și latinismele și italienismele utilizate; unele dintre acestea apar adaptate sistemului fonetic și morfologic al limbii române, iar altele reprezintă apariții efemere, cu atestare singulară.

\section{Bibliografie}

Gheție, I. (1975). Baza dialectală a românei literare, Editura Academiei, București.

Micu, S. \& Șincai, Gh. (1780). Elementa lingue daco-romane sive latino-valachice, Buda; ediție critică, studiu introductiv, traducerea textelor și note de M. Zdrenghea, Cluj-Napoca, 1980.

Munteanu, Șt. \& Țâra, V. (1983). Istoria limbii române literare. Privire generală, Editura Didactică și Pedagogică, București.

Slave, E. (1962). Sufixele-ie, -ărie, în Studii și materiale privitoare la formarea cuvintelor în limba română, III, București, 1962.

Ursu, D. (1969). Adaptarea adjectivelor neologice în limba română literară din perioada 1760-1860, în „Studii de limbă literară și filologie”, I, București, 1969, p. 131-154.

Ursu, N.A. (1961). Cărți de popularizare a științei traduse de Petru Maior, în „Limba română”, X, nr. 2, p. $135-143$.

Ursu, N.A. (2012). Alte două traduceri necunoscute ale lui Petru Maior, în „Limba română”, LXI, nr. 3, p. 413-416.

\footnotetext{
${ }^{11}$ Cuvîntul poate fi și un împrumut din macedoromână (ermu 'pustiu').

${ }^{12}$ În italiană, cuvintul este adjectiv (< lat. esculentus '(bun) de mîncare'). P. Maior îl folosește ca substantiv: “[...] să fie necesitați sau strimtorați de foame a devora adecă a mînca sterc (balega) strein și esculente adecă bucate putrăde”.
} 